\title{
ETHNOGRAPHY FROM THE INSIDE: IndUStry-BASEd ReSEARCH In the Commercial Sydney EDM SCENE
}

\author{
$\bullet$ Feature Article $\longrightarrow$ \\ ED MONTANO \\ RMIT UNIVERSITY (AUSTRALIA)
}

\begin{abstract}
Drawing on a decade of ethnographic research and participant observation in the Sydney commercial electronic dance music (EDM) scene, this article explores some of the issues and tensions in conducting industry-based fieldwork in EDM culture. Through interviews with some of the scene's key DJs, promoters, media workers and other industry personnel, consideration is given to designing a set of guiding principles for researchers undertaking "behind-the-scenes", localised EDM research. The starting point for my discussion is my work in dance music retail, specifically at Central Station Records between 2002 and 2005. The level of access this work granted me to particular industry workers and the subsequent networks I was able to establish proved invaluable to my research not only when seeking out interviewees but also when seeking entry to clubs and events. However, while insider knowledge has numerous benefits, convincing contacts of the relevance of research can be problematic, as can maintaining a critical distance.
\end{abstract}

KEYWORDS: DJs; ethnography; Sydney; insider research; participant observation

Ed Montano is Lecturer in Music Industry at RMIT University, Australia, and writes for the Australian dance music website <www.inthemix.com.au $>$. He is Reviews Editor for Dancecult and is on the Executive Committee of the International Association for the Study of Popular Music. Email: <ed.montano@rmit.edu.au>.

Dancecult: Journal of Electronic Dance Music Culture 5(2): 113-130

ISSN 1947-5403 @2013 Dancecult http://dj.dancecult.net

DOI 10.12801/1947-5403.2013.05.02.06 


\section{INTRODUCTION}

THIS ARTICLE considers some of the issues I have negotiated during ten years researching the commercial club scene in Sydney (see, for example, Montano 2009 and 2010). Taking cues from Hodkinson's analysis of insider research (2005) and Lau's discussion of ethnography and reflexivity (2012: 18-25), I believe it is essential to discuss, critically analyse and reflect upon one's role as an ethnographer as well as how one's position in relation to the field impacts research. Such analysis is crucial, given that "holding a degree of insider status clearly can have implications for the achievement of successful and productive interactions with participants" (Hodkinson 2005: 136), while being an insider researcher presents both advantages and challenges (Lau 2012: 18). Through detailing my reflections on my fieldwork of the past ten years, my intention here is to offer guidance for those commencing research in similar contexts, specifically industry-based analysis in urban EDM scenes. My research has involved numerous interviews (together with more informal conversations) with DJs, promoters, media workers and other industry personnel. I took this approach in an attempt to distinguish my work from the focus on audiences/clubbers that dominated the academic literature on EDM culture at the commencement of my research in 2002, ${ }^{1}$ and from "the literature on dance club cultures which situate youth as not only a central but almost an exclusive condition of participation" (Bennett and Taylor 2012: 238). I identify the three areas of "reflection", "transition" and "integration" that need to be taken into consideration when undertaking fieldwork research as an insider.

I spent the years between 2002 and 2005 working as a retail assistant on the CD counter at Central Station Records (and subsequent years working at other music retail stores). At the time, this was Sydney's main independent EDM store and was part of the Central Station Records group that included other stores around Australia and a record label that has had a significant role in the popularisation of EDM in Australia. The industry-related benefits of working in the store allowed me to further my research on Sydney's clubbing landscape. I took full advantage of the opportunities for free entry into most of the city's clubs that working alongside DJs provides. All those employed to work behind the store's vinyl counter were professional DJs, while dance party promoters would often visit the store to leave flyers or posters for their events, typically offering guest-list places or free tickets for any staff. I was thus able to form a network of contacts that proved beneficial not only when seeking out interviewees but also when seeking entry to clubs and events. While I was always careful not to appear to be exploiting a friendship for personal gain, I certainly enjoyed the benefits of being placed on a guest-list, and I certainly went out clubbing more often than I would have had I been required to part with my own money to gain entry. My work at the store also enabled me to gauge the dimensions of the Sydney scene, through CD, vinyl and ticket sales. The job took on a degree of schooling, in that I was constantly being educated about the styles of music that were popular with Sydney clubbers, the venues that were pulling the biggest crowds, and the discourses and value judgements that circulated within the scene. This work informed my ethnographic research 
in numerous ways, establishing boundaries, generating ideas and providing directions. The conclusions I have drawn about the EDM industry in Sydney are rooted firmly within the experiences and encounters I had while working at the store. The job afforded me an insight in to the city's club culture that could not have come from any other source or method of investigation, and allowed for an intensity of participation within the scene that acted as a solid foundation for my subsequent analysis.

As a method of research into music scenes, ethnography has been, and remains, a useful and productive approach. Extending and deepening this method, participant observation is frequently thrown into the mix, with researchers drawing upon their own personal involvement with the music and its associated cultural field. Despite the overlap between the two approaches, it is important to note that a distinction can be made between insider ethnography and participant observation. An insider can employ an ethnographic methodology that is not necessarily participatory, while an outsider can engage in participant observation. For the researcher who engages in insider-based participation, negotiating their own involvement in the scene under study is crucial for a successful project. Yet there has been very little consideration and interrogation in music-scene discussion of the processes of such research tactics. While many studies of EDM cultures are grounded in detailed and extensive fieldwork, ${ }^{2}$ these rarely engage with critical analysis of fieldwork. Alongside these studies there is a growing body of Australian-focused and Sydney-specific research on EDM. ${ }^{3}$ More broadly, there is a range of popular music ethnographies that have been particularly useful for understanding the methods that are most appropriate for studying a specific scene in a particular cultural context. ${ }^{4}$ This article is intended to complement this existing work.

\section{INSIDE AND OUTSIDE}

DURING the course of my research I occupied multiple positions. I made a deliberate effort to remain an active participant in the scene, as an "insider", while being conscious to step back and critically analyse my research findings as an "outsider". This separation allows for a distinction to be made between the different roles that can be adopted during the research process. Furthermore, it demonstrates a critical awareness of the tensions and porous boundaries that reside between these roles. A deconstruction of insider participatory activity and its impact on research is facilitated by stepping back from one's own involvement (Cummings 2006: 70), avoiding what Taylor describes as "insider myopia" (2011: 16). Yet this is complicated by personal investment in the music and the scene. It was my own knowledge of and passion for dance music and club culture that drove me to investigate the scene in Sydney. My enthusiasm remained strong throughout my research activity, compromising the objectivity of my analysis. However, it was this passion that enabled me to secure employment at Central Station Records, which I combined with my album and gig reviewing contributions to Australian dance music website www.inthemix. com.au (ITM). ${ }^{5}$ Together with my regular clubbing adventures, I was able to look at the scene from multiple vantage points. 
This integration into the scene allowed me to establish relationships with scene actors that subsequently generated opportunities for interviews. Similarly, my writing work for ITM opened a select few doors when it came to seeking contacts. Conducting research in record stores raises certain issues. Firstly, the gender balance (of both the workforce and customer base) is typically skewed in favour of men (or at least it was at Central Station Records and at other independent EDM stores in Sydney), and usually young men. This was reflected in the male bias of my selection of interviewees (although this selection was dictated by circumstance, not choice, with a notable lack of female DJs, promoters and industry workers in Sydney). Secondly, as salespeople, store workers can influence a DJ's choice of music by making recommendations. My colleagues and I would receive enquiries from several DJs on a weekly basis about having "anything good in the orders". Store workers therefore have a central role in shaping the musical landscape of particular scenes. Thirdly, these workers can influence the networking structures of the scene by introducing DJs, promoters and other industry personnel to one another. In light of all this, the insider researcher who works in a record store is a pivotal scene participant, capable of influencing the actions of other scene members.

My fieldwork also involved interviewing DJs, clubbers, promoters, journalists and other industry practitioners about their participation in dance music culture in Sydney; in-depth analysis of local street press (free) publications and other local dance music media such as ITM; and visiting clubs and festivals. The findings generated from this fieldwork formed the roots of my study. Fieldwork is central to the ethnographic process, and my immersion in my chosen scene facilitated a research project that was embedded within the day-today working practices of many of the scene's key "social agents" (Maxwell 2002: 110). As well as providing contacts and networks, my fieldwork enabled fluency in the discourse of the scene. I made a deliberate effort to become involved in different working capacities, believing that these would enhance my reputation within the scene as an active participant and outside the scene as an engaged researcher.

Routine interactions with customers and colleagues at the record store not only enhanced my understanding of the scene but also granted me access to high-profile scene actors. In this sense, my research has involved much more than the collection of data. In an article on music radio and the record industry in the UK, Percival acknowledges how his own status as a radio insider proved invaluable for his research, arguing that empirical researchers should have expertise in their chosen field of study (2011: 460). Given the importance of incorporating a degree of self-reflection in the methodological approaches taken by researchers, relevant to any project is the history of the researcher within their chosen field. While there is certainly some validity to Tutenges' claim that "the position of 'the stranger' can help sharpen one's eyes for behaviours and assumptions that may go unnoticed for the 'culture members' themselves" (2011:4), experience and familiarity are crucial to the performance of fieldwork that is accurate and convincing.

However, experience in the field does not automatically elevate the researcher to a position more authoritative than the inexperienced researcher. Overplaying the role of 
insider, or privileging the perspective of the insider, runs the risk of failing to illuminate the multiple perspectives that research can, and should, generate. It should be noted that just as outsider views can be numerous and varied, there can also be multiple insider views (Hodkinson 2005: 141). The researcher as insider may be able to negotiate exclusive access and to source exclusive insights, yet this does not mean they "have privileged access to a singular insider truth" (Hodkinson 2005: 142), nor does it mean they are able to present "an absolute or correct way of seeing and/or reading the culture under investigation" (Taylor 2011: 6). Ultimately, there needs to be a balance between insider and outsider experiences and perspectives (Brewer 2000: 59-60; Hodkinson 2005: 145).

\section{ETHNOGRAPHY}

WiTH my emphasis on qualitative rather than quantitative data, and on my own participation in and observation of the scene, my work is grounded in the tradition of ethnography. Investigating the culture of a particular group of people is central to ethnographic research (Patton 1990: 67). Directly observing people in their social settings assists in understanding their experiences and how they make sense of these experiences (Watts 1993: 54). For popular music studies, ethnography has become a key research methodology in the investigation of the role of music in everyday life and the way music shapes the construction of personal identities, local communities and national and international scenes. As with all popular music, EDM culture has a significant role in everyday life. For this reason, ethnographic methodology is an ideal way in which to study local scenes.

My chief concern has been to obtain detailed perspectives from those involved in the commercial dance music industry in Sydney, primarily DJs, but also record store owners and workers, promoters and local media. My research has been part of an attempt to map the terrain of the Sydney scene and to explore the significance of dance music in a specific urban context. I chose not to conduct brief interviews with the greatest number of participants possible, but rather to speak in detail with selected key figures in the scene. These interviews were semi-structured, open-ended and frequently in-depth, and like Malbon's were "very much 'conversational' in style" (1999: 33). I made contact with most interviewees through my work at Central Station Records, either directly as customers with whom I had regular contact, or indirectly through networks I established during my work there. Other methods of contacting potential interviewees included telephone and email (numbers and email addresses sourced from colleagues at the store). All interviews were conducted "one-onone" and took place in locations such as bars, coffee shops and respondents' homes (Weber 1999: 321).

My selection and analysis of interview material was influenced by an overriding concern to lend voice to the scene workers who had devoted their valuable time to participating in my research. I have consistently employed direct quotation in my writing. Using interviews as primary research material foregrounds the views and experiences of those involved in the research field (Alasuutari 1995: 57; Lau 2012: 18). Direct quotations, however, are 
meaningless without any theoretical context, for as Bennett warns, "there is little to be gained from privileging empirical research over theory simply on the basis that it is somehow 'more in touch' with the object of study" (2002: 464). Interviews are inherently personal, subjective interpretations of events, experiences and developments, and, when being interpreted, need to be situated within their organizational, historical, social and geographical contexts (Negus 1999: 11).

Hodkinson suggests that being an insider "may enhance the quality and effectiveness of qualitative interviews" (2005: 138). This insider status can help to create a relaxed interview atmosphere in which interviewees are willing to disclose information that they would not share with an outsider. The existing relationships I had with most of my interviewees allowed for open and detailed discussion. While my interviews always started off in a structured question-and-answer format, they typically transformed into more informal conversations and exchanges. Ultimately, I would suggest that the more informal the interview, the more relaxed the interviewee, and thus the more potential for discussion of topics that perhaps would not arise in a more formal, structured interview, with increased trust and conversational flow facilitated through the informality (Hodkinson 2005: 139).

Sydney was chosen for this research because of the city's history of involvement in dance music, paralleling Cohen's decision to focus on Liverpool in her study of rock culture in a local context (1991: 4). Furthermore, when I started my research, little attention had been given to commercial dance music culture in Sydney, paralleling Bennett's decision to study dance music in Newcastle upon Tyne (2000: 3). Sydney is generally perceived to be "the dance capital of Australia" (Park and Northwood 1996: 2), while the city's DJs, clubs and festivals reflect the global diffusion of contemporary EDM culture. Located on the periphery of the dominant stream of Anglo-American music industry production, Australian scenes balance their own specific local inflections with imported music, styles and fashions. During my research I observed tensions in fan and media discussions of the local and the global, with numerous debates in the press and online forums on the value of local DJs versus international DJs and local production versus international production. These tensions are highlighted by Sydney DJ and producer Goodwill when he explains how international DJs are often perceived by clubbers within the scene as being superior to their local counterparts:

One thing that annoys me these days is how much people look up to international DJs. Quite often it will take an international DJ to come out here and play a record for kids to think it's good. They'll play a big tune that I've been playing for three months and everyone will go, "Oh, what's that?". The other thing is the changing of technology. I've been playing CDs for ages and copping a bit of flak for it at regional gigs, but then Erick Morillo will come out and play all CDs, and no one will say anything. It's just because they're from overseas people automatically assume that it's a good thing, although at the same time they pack out dance floors and turn people on to music, so there's pros and cons to it. ${ }^{6}$ 


\section{Local Ethnography in Global Contexts}

WHEN I commenced my research there was little material that related directly to the ethnographic research of dance music and club cultures, Malbon highlighting just a few years earlier how "ethnographies of clubbing are especially scarce" (1999: 180). Ethnography seemed the most suitable methodology for the industry-based analysis I wanted to undertake, although at the same time I remained aware of Kirschner's criticism that territorially-bound ethnographies, such as Cohen's, Finnegan's and Shank's, "fail to link intimate accounts of local practices to the bigger picture, reducing complex flows of popular culture to a sort of local determinism" (1998: 258). Thus, I attempted to situate my study of the Sydney scene within a wider transnational context of global EDM culture. For Kirschner, the boundaries or territorial limits of ethnography (as defined by the field being researched) make it difficult for the ethnographer to make connections between their findings and wider global influences (1998: 259). However, through my research I aimed to challenge this. Ethnographic study, rather than privileging the local as Kirschner argues, can be applied to a wider context and can thus enhance our understanding of a global industry and culture. Ethnography that focuses solely on the micro-level ignores macro-level phenomena such as transnational flows. ${ }^{7}$ One response to these flows is the development of "multi-sited ethnography" (Marcus 1995), an example specific to EDM being D'Andrea's "macro-ethnography" of Ibiza and Goa (2007).

Contemporary music scenes develop through the interweaving of local and global resources (Bennett and Taylor 2012: 234). Thus, to contextualise the Sydney commercial EDM scene, I have considered not only the thoughts and actions of those involved in the scene but also the scene's global environment. I have conducted work on a particular locality with a view to its articulations within broader cultural and economic systems (Straw 1991). My work is not multi-sited in the sense that I physically travelled to different geographical locations to conduct comparative research, but it is grounded in my background as a British citizen. My knowledge and experience of EDM culture in England informed my research on a variety of levels, and I would argue enabled me to situate my discussions in a broader, multi-sited, global framework. Like the British backpackers who staged dance parties and raves in Sydney in the late 1980s and early 1990s based on English models of the warehouse party, I too was an "expat" combining my homegrown knowledge with a cultural activity in a foreign land. My understanding of the UK dance scene, when placed alongside and in contrast to my exploration of the Sydney scene, granted me an increased sense of the fluidity and interaction between dance music scenes around the world.

My initial involvement in the commercial Sydney EDM scene took place during the six months I spent in the city as part of my twelve-month working holiday in Australia between 1999 and 2000. Both prior and subsequent to this holiday, I undertook undergraduate and postgraduate study in Liverpool. Alongside its rich rock music heritage, the city gave rise during the 1990s to Cream nightclub, and Cream's subsequent development into a global brand of club culture meant that Liverpool became a cultural epicentre for dance music, 
"with the rampant hedonism of dance fans paralleling the prevailing politics of self-interest" (Nehring 2007: 3). It was this vibrant and increasingly commercial scene I fell into when I commenced university life during the latter half of the 1990s, and so did many others, with one of the reasons often cited for Cream's success being the city's bustling student population.

Moving to Sydney in 2002, I found that the change in location led to a shift in my EDM tastes. At the time, the city's commercial scene was dominated by the deep and funky end of the house music spectrum, which contrasted to the more progressive sounds I had been used to hearing in Liverpool. Through both my fieldwork and my job at Central Station Records, I developed an intense appreciation of deep, soulful house. Venues in the city such as Home, Tank, YU and The ArtHouse catered widely to fans of this music, providing many memorable nights out during the course of my research. My own passion for house music, combined with the centrality of this music to dance culture in Sydney, led to my research engaging mainly with DJs who played in the commercial house music scene in the city. ${ }^{8}$

Many of my conclusions regarding the place of Sydney within global EDM culture are informed by my experience of club culture outside of Australia. Of course, not all researchers are able to draw on direct experience of other scenes. This does not mean, however, that local research cannot be situated in a global context. The development of communication technology has made it easier to establish contact with participants in scenes all over the world. As well as utilising the wide array of international media now circulating through global EDM space, researchers can draw on local scene DJs who work internationally. Such people can have an intimate knowledge of scenes elsewhere and of the global terrain of EDM culture. Similarly, researchers can consult international DJs who pass through their scene (although gaining access is not straightforward), as well as tourists who temporarily participate in the scene. Discussing the emphasis that is placed on international DJs by promoters within the Sydney scene, DJ and producer Seb Chan acknowledges the demands of tourists:

Sydney is a big tourist city. We get more tourists than any other city in Australia. The Sydney scene, by that measure, will have more people coming from other countries than, say, Perth or Melbourne.... Who are the people who are in a place to party? Generally backpackers and tourists. Your general workers go out maybe once a month, twice a month, unless they are particular ages. The Olympics [in 2000] made us much more [of] a tourist city, and I think subsequent to the Olympics, we've had a lot more focus on [how] your core audience is going to be maybe thirty per cent, forty per cent tourists. So what are tourists going to know? They know the big names from back home. That's my general vibe. The tourists aren't here enough to realise necessarily that the local [DJs] are as good or better. Tourists are a very different demographic because, by their nature, they are freed up from the restrictions or rules of their other life back home, so as a tourist you do things you wouldn't otherwise do, and that's the lifeblood of commercial clubs for sure.? 
Research on local music scenes needs to be connected to the broader transnational processes that facilitate the global spread of culture. The written histories of EDM may emphasise the role of place in the music's development, as with Chicago and Detroit for example, but in the contemporary context there is an impression of globalism, as Sydney DJ Alan Thompson ${ }^{10}$ acknowledges:

I think the dance music scene as it is today is completely imported, all around the world, from the UK. I do really believe that. Having DJed since 1990 and travelled all over the world, I've seen various countries change over the years, and what is predominant in that change is that the clubs themselves are marketing themselves, and their music policies, and the DJs, to what the UK does. You could stand in a club in Tokyo, in Montreal, in New York, or Singapore, or even Sydney, close your eyes and without knowing what is going on you could be in a club in England.... The dance scene has a worldwide identity. I really believe that dance music is a world phenomenon, and we are all dancing to the same beat, but in different countries. ${ }^{11}$

Thompson's British background could possibly be an influencing factor on this characterisation. The Anglo-centricity of his perspective creates the impression of a centreperiphery model where all dance music activity radiates out of the UK. This would be an over-simplification of the complex circulatory patterns of transnational cultural flow that exist between different scenes. Thompson also overlooks Australia's historically shaped Commonwealth political and cultural ties with the UK, meaning that the influence of UK EDM culture in Australia mirrors a broader and longer pattern of Australian cultural activity developing in the shadow of Britain. As such, it is unlikely that Thompson's analysis would apply to scenes in non-Commonwealth states.

Conducting contemporary site-specific ethnography is complicated by the shifting and continually evolving scenes that arise out of the global flow of culture. During the course of my own fieldwork there has been a mainstreaming of EDM culture in Australia that has generated particular changes in the Sydney scene, notably the increased prominence of daytime festivals and the partial disappearance of regular club nights. This shift to the mainstream is highlighted by Sydney promoter and DJ John Wall:

When we started promoting, [the Sydney dance scene] was small. There weren't that many venues that people could use for dance things. I'm talking about [the] mid-'90s. There was Underground Café, which is currently Candy's Apartment, and they had a regular deep house night every Friday which did alright, and people like Derrick Carter and Mark Farina had their first Sydney gigs there, and then there were lots of small one-offs and things.... Then over the last few years of the '90s, up to about 2002, it stayed similar, but we were growing, and a couple of the other promoters got sick of it and lost interest a bit. It was still the thing where there was a fairly obvious division between the dance crowd and the mainstream, where even dance music that I wouldn't consider even remotely underground at all, like Groove Armada or something, was still not fully mainstream, and if you went to some mainstream bar 
or pub or club, that would be Top Forty [music] and it would be different kind of people and a different kind of vibe, and everyone in the dance scene would look kind of scruffy, nobody would be wearing high-heels, and it had a very different vibe. Now, I don't think there's any clear division at all, it's much more spread, there's a lot more middle ground. What goes on week-to-week, there aren't that many underground nights where it's just all about the music. There aren't that many regular nights where everyone is there for the music and not for the fashion. ${ }^{12}$

Any scene study represents a snapshot of a moment in time. A scene's ever-changing shape immediately renders any writing historical. Thus, as Fikentscher suggests, "any sound ethnographic methodology should come to terms with the time dimension of its topic" (2000: 17). Indeed, throughout the course of my own research I have negotiated a continually metamorphosing Sydney commercial EDM scene, the constantly shifting cultural terrain of dance music making itself evident in the way various clubs, events, DJs, promoters, record stores, media and music have come and gone. Such changes are by no means unique to Sydney, and I believe that acknowledging cultural shifts is an integral part of the ethnographic process. Maintaining an awareness of scene change is crucial in negotiating the inherent temporal boundaries of any ethnographic project. This awareness can be enhanced if the researcher reflects continually on their progress, considers the politics of their transition from insider to insider-ethnographer, and makes an explicit attempt to become an integrated part of their scene. I now turn to these three areas of reflection, transition and integration, and how I perceive them as intrinsic components of conducting insider research.

\section{REFLECTION}

BEING ABLE TO REFLECT CRITICALLY on one's position as a researcher is an essential part of conducting an informed project. During my own research I regularly assessed how I portrayed myself within the scene as an insider, alongside a consideration of my ability to detach myself from the fan perspective. Reflection is a crucial element of fieldwork methodology, as it allows the researcher to uncover and interrogate their biases. Bennett (2002) discusses the necessity for self-reflection in the methodological techniques employed by researchers studying youth culture and popular music, and emphasises the extent to which researcher familiarity with the field can influence findings and subsequent theorisation. He summarises the absence of empirical research in early approaches to the study of youth culture, and suggests that the emphasis on theory in these approaches has resulted in a lack of concern for detailed ethnographic work which has, in turn, generated a lack of engagement with "methodological issues such as negotiating access to the field, management of field relations and ethical codes" (2002: 451). Bennett goes on to outline an approach to researching youth culture in which the researcher incorporates a degree of selfreflection. Qualitative research methodologies, he argues, should display a critical analysis of the relationship the researcher has to the field being studied. I believe my position as a 
"fan" of dance music and as an active participant in EDM culture allowed me to pursue a more detailed and informed analysis of the Sydney scene. Bennett suggests "there may be much to learn about the social significance of contemporary youth cultures and musics using an approach which combines critical reflexivity with an intimate knowledge of fan discourse" (2002: 462). Similarly, I believe there is much to learn when using the same approach to analyse music industry discourses and practices.

\section{TRANSITION}

HODKINSON DESCRIBES the shift in positioning he experienced after deciding to research the goth scene in which he had been an active participant. Moving from an insider to the dual role of insider and ethnographer, involvement as a fan was now balanced with "observing, interviewing and analysing the goth scene and its participants in relation to continual reading, writing and academic discussion" (2005: 136). Thus, when deciding to research a field in which they are actively involved, the ethnographer makes the transition from insider to insider researcher. It is important to be aware of how this transition is managed, and of how any involvement at the fan level is impacted by the practice of research and analysis.

One issue I negotiated in my own transition involved explaining to contacts why I wanted to interview them and convincing them of the relevance of my research. While most were happy to spare an hour or more of their time, a select few proved somewhat more reluctant to speak to me, and these were often the people I was particularly keen to speak to. This may have been related to their higher profile within the scene, and thus they perhaps felt speaking to someone who was not going to provide them with direct promotion (as a music journalist would) was not an efficient use of their time. Despite my attempts to convince them otherwise, usually through stating "I work at Central Station Records", my insider status did not always prove to be the access key I hoped it would. On more than one occasion I was left standing on a street corner or sitting in a café waiting for interviewees who ultimately never turned up and never bothered to notify me that they could not make our appointment. Perhaps naively, I had assumed that my position as an active scene worker would grant me a degree of authority and would open all doors to all participants. Thus, I think it is important not to paint insider research as opening a gateway that cannot be opened by the outsider. Indeed, in some cases I believe it may have been more effective for me to not mention my work at the record store, and instead to emphasise my detachment as an outside researcher seeking to investigate the working practices of the scene's key figures. In retrospect, I would suggest I perhaps over-emphasised or over-played my status as an insider, which possibly translated to an undermining of the purpose and relevance of my research.

Transitioning into scene-insider status can potentially be affected by scene politics. The researcher should be aware of how the alliances they make with particular people may inhibit access to others, due to antagonisms between artists, disagreements between promoters, or other conflicts. As such, while being an insider can remove certain boundaries, it can also 
create new ones. That said, while there is certainly a healthy level of competition amongst some of the DJs and promoters in Sydney, I did not uncover any hostility or distrust. Furthermore, my role at Central Station seemingly had no impact on the willingness of workers at other record stores to speak with me. Yet even though there were no explicit boundaries that prevented me from accessing particular people, I still had to be aware of how the connections I made as an insider, and the communication I had with various scene actors, could potentially impact on further networking and interaction. Related to this, it was important to ensure certain interview material remained confidential. For example, one DJ was particularly critical of the managers of a club at which he played, attacking them for imposing guidelines and recommendations for the type of music he should play during his sets. While I did not interview the managers, I felt it would have been inappropriate to include the DJ's comments in published work. I could have incorporated them as an anonymous response, but I was reluctant to present material that could potentially cause problems between scene participants and for my own future research. In this regard, my decisions on what to include and what to exclude have been partially influenced by my transitioning to the role of insider researcher and my desire to protect my image and reputation within the scene. Fortunately, on occasions where potentially sensitive observations were being made, most interviewees were careful enough to withhold any identifying information, as the following quote from Sydney DJ John Devecchis demonstrates, when discussing the role of the warm-up DJ:

You know the track "So Much Love to Give" $?^{13}$ I saw one of the warm-up DJs at Home nightclub once, I won't mention his name, a few years ago when the track was massive. He warmed up for an international, and he was doing a good job, and as his last track before the international came in he played "So Much Love to Give". I've never in my life questioned a DJ doing something before as much as I did that. He played the biggest tune of the moment as the very last track before an international came on. He peaked the crowd to the biggest they were going to get peaked all night, just as this poor international was coming on to play. It was the most unprofessional thing I've ever seen in my life. It was stupid. What's the point of booking an international if your warm-up DJ is going to outdo him? The job of a warm-up DJ is to get the crowd warmed up, get a groove, and get people on the dance floor. The ones who try to steal the limelight shouldn't be warming up for internationals, basically. ${ }^{14}$

Aside from the scene specifics that relate to the transition process, the journey of the insider researcher is also bound up in the broader scientific community surrounding their scholarly work. Research results are discussed critically through conference presentations, interaction with other researchers and the publication of journal articles and other texts. Through these endeavours, the insider researcher transitions into the EDM research community. The transition process thus involves both the culture of the scene and the culture of academia. 


\section{INTEGRATION}

Through my employment at Central Station Records, the degree of integration into the scene that I achieved was arguably higher than had I been merely a clubber and listener. There was a certain amount of luck and good fortune in my obtaining the job, and such employment opportunities are rare in EDM scenes, particularly when you have no contacts or networks in the scene. Furthermore, the disappearance of record stores has meant the loss of one of the key sites of employment and social interaction in EDM culture. This sociality of record shopping was highlighted by Alan Thompson prior to the closure of most of Sydney's DJ record stores:

From a DJ's point of view, one of the parts of my job that I absolutely love is going to a record shop and listening to music and buying the music. Going record shopping on a Thursday or a Friday can be a social thing. You'll see other DJs there, well not so much in Sydney, but in London for instance you'd bump into producers and they would pass on their new tune, so it's much more of a social gathering for DJs as well. It's a meeting point. We only get to see each other on a very rare occasion that we might be playing at the same club, whereas on a Friday afternoon at Black Market in London you can guarantee that most of the top DJs in London will be in there at some point in the day. ${ }^{15}$

At the time of our first interview in 2005 DJ Mark Murphy was co-owner of Sydney's Spank Records (which finally succumbed to the pressures of digital downloading in 2011), and understandably held out hope for the continued existence of record stores:

I hope record stores will still be around in future. Either that or I've sold it for a fortune! People do still like the contact and the feeling of coming into a store and listening to vinyl and getting good customer service. I think people still enjoy that. I'd like to think that [the record store] is very important [to dance culture], just for the fact that I co-own one. It is a very social factor. You sort of promote the local scene more when you have a store because it becomes a focal point. You're selling tickets to parties. I think it is very important. I think it would be sad if there was no dance music store and everyone was buying off the Internet. It brings the local scene a little bit more together. ${ }^{16}$

Eight years later, and with the six record stores that used to be located in the inner-city suburb of Darlinghurst all now out of business (including Central Station), it is clear that the easier accessibility and wider variety of music online has seen most DJs shun the social experience facilitated by record stores in favour of digital files. This has arguably made it harder for researchers to stake out key dance music sites. ${ }^{17}$ Nonetheless, the concept of integration remains useful when planning fieldwork. I'm not suggesting that such integration needs to take the form of paid employment but rather that research is validated by any kind of immersion in the scene. Such immersion can take many forms. My experience suggests participation, integration and immersion generates insights, contacts and friendships that 
impact positively upon research. Had I not worked at Central Station Records I'm sure I would have found other avenues to pursue potential interviewees and to uncover research topics. However, I am also sure that any interview responses would have been less detailed and less open. I believe my integration into the scene made interviewees more willing to disclose certain information and more willing to be interviewed in the first place. Through my work I was able to establish a rapport with some of the scene's key players (Cummings 2006: 70; Lau 2012: 21; Taylor 2011: 6).

\section{CONCLUSION}

SPECIFIC geographical contexts are rich in ethnographic detail. Those who participate in a particular culture on a regular basis are well positioned to explore and assess the operational logics of that culture. Discussing the aims and intentions of ethnographic studies of dance music culture, Seb Chan emphasises the importance of uncovering the local particularities of any one scene that serve to distinguish it from scenes elsewhere. He also goes on to suggest that the commercial structure that underpins contemporary EDM makes the scene itself a more detailed and complex, although at the same time more easily accessible, field of study than it was fifteen years ago when he was researching a thesis on EDM culture:

I think any research on this sort of culture needs to reveal the local specificities that make things happen here rather than somewhere else. That's always what I've been excited about. I've always been curious as to why does 'this sound' work in Sydney, but not work 'there'. Why is that? Why is my audience generally 'this' age and not 'that' age? What is it about the music? Is it about the music? Is it about the marketing? Is it about a combination of the two? I think it's become really complicated now. There's a lot more capital involved, and so you get the flow of things like marketing impacting upon it in a big way, and perhaps you didn't before. You get companies buying up clubs, like the Merivale Group, Justin Hemmes ${ }^{18}$ and all these people who have very particular strategies, and they have teams of marketers working with them to make sure that 'this' venue feeds people to 'this other' venue, that you track people across time. When they grow out of one club, like Sublime, where are they going to go next? It's a lot more grand-scale than it was when I was writing about it. I was writing about those formative stages. I think now it's probably a bit easier to write because you can look at those grand plans and you can speak to those people. [Now] it's both more complicated but more accessible too. ${ }^{19}$

The commercial dance music scene in Sydney provided me with a rich and fertile site for study. Rather than focus on audiences, I situated the DJ at the centre of my research. Through exploring the ways in which certain DJs in Sydney discuss their work, it is possible to see how these DJs interpret their role within the city's dance scene and the way they perceive and understand this scene. More broadly, working through issues related to DJ practice in a specific setting helps to construct a more informed understanding of contemporary EDM culture, in both local and global contexts. As EDM cultures continue to expand globally, 
it is necessary to adopt methodological approaches that are rooted in the local and at the same time engage with the global. Such approaches would be more fruitful and would offer a more accurate picture than focussing on one specific site of research. Conducting future ethnographic research into EDM cultures using research designs imbued with this global perspective could help overturn the Euro-/Anglo-centrism characterising existing research (my own included) on EDM scenes.

\section{ACKNOWLEDGMENTS}

Thanks to Luis-Manuel Garcia, Graham St John and the anonymous reviewer for their feedback on earlier drafts of this article.

\section{NOTES}

1 In the journalistic/non-academic literature on EDM, the opposite has tended to be the case (e.g. Brewster and Broughton 2000; Reynolds 1999). A rather classic "great artists and their works" historiography is also present in these more historical accounts.

2 Ahmed, Benford and Crabtree 2012; D’Andrea 2007; Fikentscher 2000; Gibson and McGregor 2011; Malbon 1999; Olszanowski 2012; Reitsamer 2011; Thornton 1995.

3 Brennan-Horley 2007; Brookman 2001; Chan 1999; Gibson and Pagan 2003; Luckman 2002; Murphie and Scheer 1992; Park and Northwood 1996.

4 Bennett 2000; Cohen 1991; Fikentscher 2000; Finnegan 1989; Malbon 1999; Rietveld 1998; Shank 1994.

5 See $<$ http://www.inthemix.com.au/people/e_j_montano/portfolio/articles $>$ (accessed 15 September 2013) for my portfolio of reviews.

6 Goodwill, interview with the author (Sydney), 8 September 2004.

7 Appadurai 1996; Connell and Gibson 2003; Ho 2003; Kong et al. 2006; Negus 1996.

8 See Gibson and McGregor (2011) for a discussion of the development of the Dunedin house music scene between 2002 and 2008. This development closely paralleled what took place in Sydney during the same time, at least in terms of shifts in audience preferences for particular styles of dance music. McGregor's Sydney-based girlfriend would send him monthly packages of records bought from Central Station, so that his "record box echoed with the beats that were popular at the time in Sydney" (2011:209).

9 Seb Chan, interview with the author (Sydney), 25 August 2005.

10 Prior to moving to Australia in 2004, Thompson lived and worked in the UK and therefore is particularly well placed to comment on the international scope of dance culture.

11 Alan Thompson, interview with the author (Sydney), 15 June 2006.

12 John Wall, interview with the author (Sydney), 20 July 2008.

13 "So Much Love to Give" was a hugely popular track in the Sydney dance scene during 2002 and 2003. Credited to Together, it was composed and produced by DJ Falcon and Thomas Bangalter, and was initially released on Roulé Music in 2002.

14John Devecchis, interview with the author (Sydney), 24 September 2006. 
15 Alan Thompson, interview with the author (Sydney), 15 June 2006.

16 Mark Murphy, interview with the author (Sydney), 23 June 2005.

17 The development of online spaces as providing networking opportunities perhaps demonstrates how industry workers have responded to the disappearance of record stores. See, for example, Reitsamer (2012) for an analysis of the Female Pressure network.

18 Justin Hemmes is head of the Merivale Group, a Sydney-based hospitality company that operates various bars, clubs and restaurants in the city such as Establishment, Slip Inn and Ivy. In previous years, the company also operated iconic Sydney house music venue Tank, as well as staging the annual Good Vibrations festival between 2004 and 2011. I made contact with the company on five separate occasions to request an interview with Hemmes, and after having been re-directed to several different people, no replies to these requests were forthcoming. I probably would have been more successful had I posed as a journalist from an ultra-chic style magazine.

19 Seb Chan, interview with the author (Sydney), 25 August 2005.

\section{REFERENCES}

Ahmed, Ahmed Y., Steve Benford and Andy Crabtree. 2012. "Digging in the Crates: An Ethnographic Study of DJs' Work". CHI 2012 Proceedings of the SIGCHI Conference on Human Factors in Computing Systems: 1805-14. < http://dl.acm.org/citation. cfm?id=2208314 $>$ (accessed 02 December 2012).

Alasuutari, Pertti. 1995. Researching Culture: Qualitative Method and Cultural Studies. London: Sage.

Appadurai, Arjun. 1996. Modernity at Large: Cultural Dimensions of Globalization. Minneapolis: University of Minnesota Press.

Bennett, Andy. 2000. Popular Music and Youth Culture: Music, Identity and Place. London: Macmillan. - - - 2002. "Researching Youth Culture and Popular Music: A Methodological Critique". British Journal of Sociology 53(3): 451-66.

Bennett, Andy and Jodie Taylor. 2012. "Popular Music and the Aesthetics of Ageing". Popular Music 31(2): 231-43.

Brennan-Horley, Chris. 2007. "Work and Play: Vagaries Surrounding Contemporary Cultural Production in Sydney’s Dance Music Culture”. Media International Australia 123: 123-37.

Brewer, John D. 2000. Ethnography. Buckingham: Open University Press.

Brewster, Bill and Frank Broughton. 2000. Last Night a DJ Saved My Life: The History of the Disc Jockey. London: Headline.

Brookman, Chris. 2001. “Forever Young': Consumption and Evolving Neo-tribes in the Sydney Rave Scene". BSc Dissertation, Geosciences, University of Sydney.

Chan, Sebastian. 1999. “Bubbling Acid: Sydney's Techno Underground”. In Australian Youth Subcultures, ed. Rob White, 65-73. Hobart: ACYS.

Cohen, Sara. 1991. Rock Culture in Liverpool: Popular Music in the Making. Oxford: Oxford University Press. 
Connell, John and Chris Gibson. 2003. Sound Tracks: Popular Music, Identity and Place. London: Routledge.

Cummings, Joanne. 2006. "It's More Than a T-Shirt: Neo-tribal Sociality and Linking Images at Australian Indie Music Festivals". Perfect Beat 8(1): 69-84.

D’Andrea, Anthony. 2007. Global Nomads: Techno and New Age as Transnational Countercultures in Ibiza and Goa. London: Routledge.

Fikentscher, Kai. 2000. "You Better Work!": Underground Dance Music in New York City. Hanover, NH: Wesleyan University Press.

Finnegan, Ruth. 1989. The Hidden Musicians: Music-Making in an English Town. Cambridge: Cambridge University Press.

Gibson, Chris and Andrew McGregor. 2011. "The Shifting Spaces and Practices of Dance Music DJs in Dunedin". In Home, Land and Sea: Situating Music in Aotearoa New Zealand, ed. Glenda Keam and Tony Mitchell, 206-15. Rosedale: Pearson.

Gibson, Chris and Rebecca Pagan. 2003. "Rave Culture in Sydney, Australia: Mapping Youth Spaces in Media Discourse”. < http://www.snarl.org/youth/chrispagan2.pdf> (accessed 14 September 2012).

Ho, Wai-Chung. 2003. "Between Globalisation and Localisation: A Study of Hong Kong Popular Music”. Popular Music 22(2): 143-57.

Hodkinson, Paul. 2005. “Insider Research' in the Study of Youth Cultures”. Journal of Youth Studies 8(2): 131-49.

Kirschner, Tony. 1998. "Studying Rock: Towards a Materialist Ethnography”. In Mapping The Beat, ed. Thomas Swiss, John Sloop and Andrew Herman, 247-68. Oxford: Blackwell.

Kong, Lily, Chris Gibson, Louisa-May Khoo and Anne-Louise Semple. 2006. "Knowledges of the Creative Economy: Towards a Relational Geography of Diffusion and Adaptation in Asia". Asia Pacific Viewpoint 47(2): 173-94.

Lau, Stella Sai-Chun. 2012. Popular Music in Evangelical Youth Culture. London: Routledge.

Luckman, Susan. 2002. "Party People: Mapping Contemporary Dance Music Cultures in Australia”. Ph.D. Dissertation, University of Queensland.

Malbon, Ben. 1999. Clubbing: Dancing, Ecstasy and Vitality. New York: Routledge.

Marcus, George E. 1995. "Ethnography in/of the World System: The Emergence of Multi-Sited Ethnography". Annual Review of Anthropology 24: 95-117.

Maxwell, Ian. 2002. "The Curse of Fandom: Insiders, Outsiders and Ethnography”. In Popular Music Studies, ed. David Hesmondhalgh and Keith Negus, 103-16. London: Arnold.

Montano, Ed. 2009. “The Sydney Dance Music Scene and the Global Diffusion of Contemporary Club Culture". Transforming Cultures eJournal 4(1): 43-59. < http://epress.lib.uts.edu.au/ojs/ index.php/TfC/article/view/1059/1062> (accessed 23 June 2012).

_- - 2010. “'How do you know he's not playing Pac-Man while he's supposed to be DJing?': Technology, Formats and the Digital Future of DJ Culture”. Popular Music 29(3): 397-416.

Murphie, Andrew and Edward Scheer. 1992. “Dance Parties: Capital, Culture and Simulation”. In From Pop to Punk to Postmodernism, ed. Phillip Hayward, 172-84. Sydney: Allen \& Unwin.

Negus, Keith. 1996. Popular Music in Theory: An Introduction. Cambridge: Polity Press.

-_- 1999. Music Genres and Corporate Cultures. London: Routledge. 
Nehring, Neil. 2007. “Everyone’s Given Up and Just Wants to Go Dancing': From Punk to Rave in the Thatcher Era”. Popular Music and Society 30(1): 1-18.

Olszanowski, Magdalena. 2012. "What to Ask Women Composers: Feminist Fieldwork in Electronic Dance Music". Dancecult: Journal of Electronic Dance Music Culture 4(2): 3-26. <http://dx.doi.org/10.12801/1947-5403.2012.04.02.01> (accessed 10 December 2012).

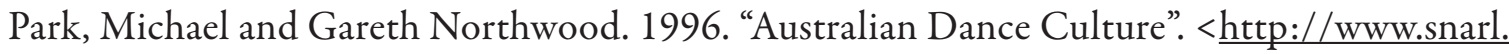
org/texts/features/dancecult2.htm > (accessed 15 July 2012).

Patton, Michael. 1990. Qualitative Evaluation and Research Methods. 2nd ed. London: Sage.

Percival, J. Mark. 2011. "Music Radio and the Record Industry: Songs, Sounds, and Power". Popular Music and Society 34(4): 455-73.

Reitsamer, Rosa. 2011. “The DIY Careers of Techno and Drum 'n' Bass DJs in Vienna”. Dancecult: Journal of Electronic Dance Music Culture 3(1): 28-43. < http://dx.doi.org/10.12801/19475403.2011.03.01.02> (accessed 15 July 2012).

- _ . 2012. "Female Pressure: A Translocal Feminist Youth-Oriented Cultural Network". Continuum: Journal of Media \& Cultural Studies 26(3): 399-408.

Reynolds, Simon. 1999. Generation Ecstasy: Into the World of Techno and Rave Culture. New York: Routledge.

Rietveld, Hillegonda. 1998. This Is Our House: House Music, Cultural Spaces and Technologies. Aldershot: Ashgate.

Shank, Barry. 1994. Dissonant Identities: The Rock 'n' Roll Scene in Austin, Texas. Hanover: University Press of New England.

Straw, Will. 1991. "Systems of Articulation, Logics of Change: Communities and Scenes in Popular Music”. Cultural Studies 5(3): 368-88.

Taylor, Jodie. 2011. "The Intimate Insider: Negotiating the Ethics of Friendship When Doing Insider Research". Qualitative Research 11(1): 3-22.

Thornton, Sarah. 1995. Club Cultures: Music, Media and Subcultural Capital. Cambridge: Polity.

Tutenges, Sébastien. 2011. "Stirring Up Effervescence: An Ethnographic Study of Youth at a Nightlife Resort”. Leisure Studies 32(3): 233-48.

Watts, Rob. 1993. "Doing Ethnography with Young People: How and Why?" In Youth Subcultures: Theory, History and the Australian Experience, ed. Rob White, 54-60. Hobart: National Clearinghouse for Youth Studies.

Weber, Timothy. 1999. "Raving in Toronto: Peace, Love, Unity and Respect in Transition". Journal of Youth Studies 2(3): 317-36.

\section{DISCOGRAPHY}

Together. 2002. So Much Love to Give. Roulé Music (12-inch): ROULE TOGETHER 2. <http://www.discogs.com/Together-So-Much-Love-To-Give/release/95130>. 